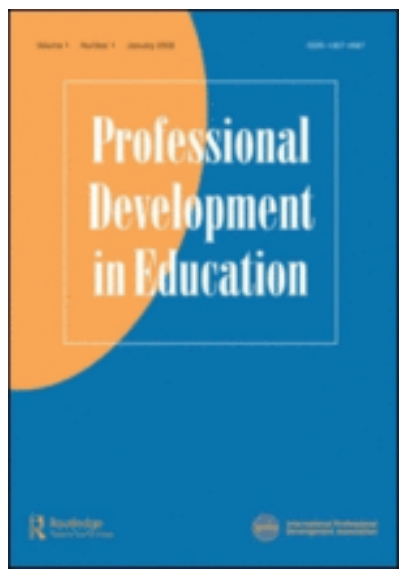

\title{
An exploration of teacher learning through reflection from a sociocultural and dialogical perspective: Professional dialogue or professional monologue?
}

\begin{tabular}{|r|l|}
\hline Journal: & Professional Development in Education \\
\hline Manuscript ID & RJIE-2019-0267.R1 \\
\hline Keywords: & professional dialogue, teacher professional learning, metacognition \\
\hline & $\begin{array}{l}\text { This study investigated how student teachers on a Scottish teacher } \\
\text { education programme learn by reflecting on professional dialogue } \\
\text { experiences. Reflection on one's own experiences and practices is at the } \\
\text { heart of all activities that teachers do. By linking professional dialogue } \\
\text { with reflective practices, we examined factors that contribute to } \\
\text { students' general approaches to professional learning on the programme } \\
\text { and the way in which meaning is co-constructed and negotiated in } \\
\text { professional dialogue. The results showed that the thought, discourse } \\
\text { and social-affective dimensions of professional dialogue are inter-related. } \\
\text { Furthermore, both student teachers' personal background and the } \\
\text { learning context may be related to their approaches to professional } \\
\text { learning. In addition, their reflection tended to be descriptive with little } \\
\text { or no consideration of the underlying educational issues or theories. } \\
\text { Moreover, there was a tendency for one speaker to dominate } \\
\text { professional dialogue or rather 'professional monologue'. Therefore, we } \\
\text { argue that there is a need for teacher education institutions to develop } \\
\text { student teachers' awareness of the value of professional dialogue and of } \\
\text { the dialogic space it creates which helps realise its potential as a tool for } \\
\text { transforming professional learning. }\end{array}$ \\
\hline
\end{tabular}

\section{SCHOLARONE Manuscripts}




\title{
An exploration of teacher learning during initial teacher educationthrough reflection from a sociocultural and dialogical perspective: Professional dialogue or professional monologue?
}

\begin{abstract}
This study investigated how student teachers on a Scottish teacher education programme learn by reflecting on professional dialogue experiences. Reflection on one's own experiences and practices is at the heart of all activities that teachers do. By linking professional dialogue with reflective practices, we examined factors that contribute to students' general approaches to professional learning on the programme and the way in which meaning is co-constructed and negotiated in professional dialogue. The results showed that the thought, discourse and social-affective dimensions of professional dialogue are interrelated. Furthermore, both student teachers' personal background and the learning context may be related to their approaches to professional learning. In addition, students'their reflection tended to be descriptive with little or no consideration of the underlying educational issues or theories. Moreover, there was a tendency for one speaker to dominate professional dialogue or rather 'professional monologue'. Therefore, we argue that there is a need for teacher education institutions to develop student teachers' awareness of the value of professional dialogue and of the dialogic space it creates which helps realise its potential as a tool for transforming professional learning.
\end{abstract}

Keywords: professional dialogue; teacher professional learning; metacognition

\section{Introduction}

Teachers are often considered to be the most important agents in reforming education and in bringing about change in practices (Lieberman \& Mace, 2008). Teacher quality and how to improve it has become a key policy area for governments across the globe (Darling-Hammond, 2017; Grant, et al., 2018; Kennedy, 2015; Mayer, et al., 2016; Munthe, et al., 2011). In response to this, many countries across Europe and beyond have embarked on radical programmes of teacher education reform. For example, the teacher education sector in Scotland has undergone significant reform in multiple areas 
following the publication of Teaching Scotland's Future (Donaldson, 2011), which marked a significant turn in the conceptualisation of teacher education, professionalism and professional learning. This reconceptualisation can be broadly aligned with a move towards what Sachs (2016) describes as 'democratic professionalism', in which teachers are celebrated as autonomous and agentic professionals who are encouraged to engage in collaborative, discursive and innovative forms of teacher-led professional learning. At the same time, plans set out to reform the governance of Scottish education (Scottish Government, 2017) call for a more coherent and streamlined approach to professional learning, restricting possibilities for innovative forms of teacher learning (Kennedy \& Author, 2019). At the core of this reform, was a re-conceptualisation of professional learning, which stressed, amongst other things, the importance of teachers developing as 'reflective, accomplished and enquiring professionals' (Donaldson 2011, p. 4). This message reflects a broader movement across European teacher education reform, where reflection and inquiry are often promoted as effective forms of professional learning for both student and practicing teachers (e.g. Dolan, 2012).

This paper addresses the use of professional dialogue as a professional learning tool in initial teacher education (ITE). In this research, we aimed to investigate how student teachers on a Scottish postgraduate teacher education programme developed their professional knowledge and skills by reflecting on their professional dialogue experiences with peers, university tutors and more experienced teachers. As a way of examining professional learning, we were particularly interested in how student teachers develop their own understanding of self-regulated learning (SRL) and metacognitive processes during reflection. Endedijk et al. (2016) note that the study of SRL and metacognition holds great potential to meet the challenge of transitioning from student teachers to teaching professionals. Similarly, Wall and Hall (2016) highlight the 
important role that teachers' metacognition can play in both teacher and pupil learning. They call for all teachers to become strategic and metacognitive in their own professional learning. Sharing of thinking/learning through the means of professional dialogue with the wider community has the potential to transform the thinking and actions of the practitioner (Wall, 2017). By asking student teachers to reflect on their dialogic interactions, we hoped to gain insights into the ways in which they engaged with this complex process of professional learning.

\section{Professional Dialogue and Teachers' Reflection}

Professional dialogue permeates all stages of teachers' formal and informal learning contexts. Similar terms used in educational literature include 'learning conversation', 'reflective conversation', or 'professional discussion' (Cochran-Smith \& Lytle, 1999). Cochran-Smith (2003) argues that professional dialogue makes possible 'the learning of new knowledge, questions and practices and, at the same time, the unlearning of some long-held and often difficult to uproot ideas, beliefs, and practices' (p. 9). In the same vein, Lofthouse and Hall (2014) underline that professional dialogue is central to teacher professional learning. They argue that professional dialogue allows teachers to be aware of the changing nature of content and pedagogical knowledge and its impact on their identity. Grounded in Kemmis and Grootenboer's (2008) and Kemmis and Heikkinen's (2012) work on 'semantic space' as part of practice architecture, Lofthouse and Hall (ibid.) argue that certain elements of professional dialogue tend to be overlooked easily. They propose the Coaching Dimensions for teachers to redefine and refine our understanding about professional dialogue. It is a language-based tool to describe elements of the dialogue, including initiation, tone, interaction functions, coconstruction, emphasising the importance of discursive practices in shaping the learning process. As a social process, professional dialogue can play a key role in consolidating 
understanding of concepts shared by a professional community and, in its absence, learning is typically slower (Bereiter \& Scardamalia, 1993). Through professional dialogue, teachers can exchange their teaching experiences with one another in order to inform their professional growth. This can happen in a variety of settings: in staffrooms, departmental meetings, or professional development meetings. For student teachers, not only do they learn in all the settings above, they also learning in university settings, including tutorials, seminars or one-on-one with teacher educators. In line with Nelson et al. (2010), we argue that in order for professional dialogue to be successful, (student) teachers need to investigate their own practice and enact positive changes to both their own teaching practice and their pupils' learning experience. Therefore, professional dialogue is more than sharing of practice; it is, in effect, a tool with which teachers develop new knowledge, skills and understanding about learning and teaching.

Reflective practice in the teaching profession was first introduced in the UK through the model of reflective teaching (Pollard, 2008; Pollard \& Tann, 1987). This model proposes a cyclical approach to 'planning, making provision, acting, collecting data, analysing the data, evaluating and reflecting and then planning the next step' (Menter, Hulme, Elliot, \& Lewin, 2010, p. 23). Schön (1983) developed the notion of 'reflection-on-action', highlighting the intuitive processes of practitioners contributing ideas, questioning alternative views and supporting views with evidence, as they are engaged with the teaching. Such an understanding suggests that reflective practice is also-a deeply social process; it. Rather than a one-way communication, reflection is actually a two-way dialogic process which enables teachers to work and talk with others about the issues or problems that they have encountered in practice. From a psychological perspective, reflection is also an important tool for supporting the selfregulation processes (Pintrich, 2000; Zimmerman, 2000). Kramarski and Kohen (2016) 
argue that reflection not only facilitates student teachers' articulation of tacit knowledge, but through the process of thinking back and ahead about their understanding and teaching practice, they become increasingly competent at orchestrating a range of learning and teaching strategies. This is crucial for the development of teachers' SRL where they adopt an active approach to learning by planning, monitoring, and adapting in order to reach self-set goals (e.g. Boekaerts, 2006; Pintrich, 2004; Winne \& Hadwin, 1998; Zimmerman, 2000). Teachers' SRL is a constructive activity whereby they go through the cyclical process including goal setting, planning, monitoring and evaluating (Kramarski \& Kohen, 2016). Despite the fact that the reflective approach to ITE dominates teacher education programmes in the UK (Furlong, Barton, Miles, Whiting, \& Whitty, 2000), recent research shows that preservice teachers' reflective capacity remains limited (Michalsky \& Kramarski, 2015). Therefore, the integration of reflective practice into ITE programmes requires teacher educators to raise student teachers' awareness of reflection. Going beyond the thinking of reflective practice as a tool for professional learning and for supporting the management of the demands of practice, student teachers must be able to develop a habit of mind which involves scrutinising their teaching approaches in light of an understanding of the connections between theory and practice.

\section{Professional Dialogue as a Dialogic Process for Teacher Learning}

Research shows that student teachers in their initial career (and further beyond for some practising teachers) struggle with making full use of professional dialogue that supports quality outcomes (Hobson \& Malderez, 2013). Yet upon careful examination of the academic literature in teacher education, there is very limited research looking specifically into the relationship between professional dialogue, reflective practices and professional learning. The present research seeks to address this gap. This study adopts 
a sociocultural perspective (Vygotsky, 1978) when conceptualising the notion of professional dialogue. Such perspective highlights the relationship between thought and language use (Author, 2020). Professional learning is therefore conceptualised in a manner which focuses on the relationship between dialogue and meaning-making. Littleton and Mercer (2013) extend Vygotsky's thinking and contend that the use of language between peers in the pursuit of common goals can create new understandings. They coined the term 'interthinking' to capture the essence of this collaborative endeavour in which individuals think together to develop a shared understanding. Professional dialogue, thus, serves as a mediational conduit between learning and development for teachers. In a recent study examining teachers' discussion as part of the Lesson Study cycle and their development of pedagogical intentions in teaching mathematics, Warwick et al. (2016) identified questioning, along with building on/challenging each other's ideas, and providing reason and evidence, as important dialogic moves which contribute to the professional dialogue experiences. Such findings resonate with what Wegerif (2007) refers to as 'dialogic space' where individuals engage with each other and take each other's perspectives. The dialogic space is reciprocal and continual in that teachers are engaged in a collaborative endeavour where they co-ordinate and negotiate a shared understanding (Mercer \& Littleton, 2007). Wells (1999) notes that the dialogic process is conducive to learning. By examining teacher professional dialogue through a dialogic lens, we were looking at the positive impact of an open and in-depth communication on professional learning. This study focused on the various kinds of discourse both during campus learning and during placement learning. Underpinned by Vygotsky's (1978) sociocultural psychology, we argue that the dialogic space created by professional dialogue may play a pivotal role in 
enhancing teachers' instructional practices and in promoting professional learning through the (re)negotiation of meaning.

\section{Aims and Research Questions}

Building on current research on professional dialogue, teacher professional learning and metacognition, this paper uncovers the interplay between language use, thought and learning. Within the context of this paper, we have conceptualised professional dialogue as a sociocultural and reflective practice for teacher professional learning. This paper addresses the following questions:

(1) What factors contribute to student teachers' general approaches to learning on an ITE programme?

(2) What is the relationship between student teachers' approaches to learning and their professional dialogue experience?

(3) To what extent do student teachers perceive professional dialogue as a professional learning tool?

By investigating student teachers' general approaches to professional learning, their reflective practices and their perceptions of professional dialogue, we hope to shed light on the important role that professional dialogue plays in teacher professional learning.

\section{Methodology}

\section{Participants}

At the time of the research, the University offered a one-year Professional Graduate Diploma in Education (PGDE) course for both Primary and Secondary teacher candidates. During the ITE period, students spend half of their time studying on campus (campus learning data is marked as 'campus' in the findings section) and the other half 
working in schools (school-based learning data is marked as 'placement' in the findings $\underline{\text { section). }}$. The combination of campus-based and school-based learning provides opportunities for students to learn and interact with a range of professionals in the community: university tutors, their peers, and colleagues in schools. All students (approx. 950 students) on the PGDE programme at a university in Scotland were invited to participate in the study. In total, 99 student teachers agreed to participate in the study. However, only 43 of them (28 females, 12 males, 1 other and 2 prefer not to say) proceeded to the data collection stage. The number of the participants had an impact on the generalisation of the findings. However, due to the exploratory nature of the present study, we hope that the findings will provide some insights into student teachers' understanding of the relationship between professional dialogue, reflective practices and professional learning.

\section{Data collection}

The study adopts a mixed method research paradigm, in which both qualitative and quantitative data were collected (Cohen, Manion and Morrison, 2000). The data for the present study were collected through online survey at two points during the ITE period. The survey was designed to encourage participants to explicitly articulate, reflect and consolidate their professional learning. It consisted of three main section. In the first section, participants were asked to reflect on the following questions:

- Who was involved in the discussion?

- Who initiated the conversation?

- What was the nature of the issue or critical incident that was being discussed?

- What did they learn from the professional dialogue?

- What impact did it have on their practice/ what follow-up actions have they taken as a result of this experience? 
The qualitative data gathered from these questions helps us to understand the contextual nature of the experience. Participants were asked to reflect on a recent professional dialogue experience that occurred within a university setting (e.g. discussing course content with a tutor). In the second part, they were asked to indicate their general approaches to professional learning on the PGDE course. The same survey was used for both the reflection of university-based professional dialogue and the reflection of placement-based professional dialogue. To this end, the survey incorporated an adapted version of the Motivated Strategies for Learning Questionnaire (MSLQ) (Duncan \& McKeachie, 2005; Pintrich, Smith, García, \& McKeachie, 1993) to understand student teachers' general approaches to professional learning and the Metacognitive Discourse Awareness Questionnaire (MDAQ) to understand student teachers' professional dialogue experiences, which was corroborated with the qualitative data from part one of the survey. To our knowledge, no instrument allows researchers to examine student teachers' professional learning and professional dialogue as reflective practices.

The MSLQ (Pintrich, 2004) is one of the most reliable and widely used questionnaires for examining students' motivational and cognitive attributes in learning. You developed an adapted version of this questionnaire to explore student teachers' general approaches to professional learning. We are particularly interested their understanding of task value, self-efficacy for learning and performance and learning strategies. In this paper, task value $(\alpha=.90)$ refers to student teachers' judgments of how interesting, useful, and important the PGDE course is. Self-efficacy for learning and performance $(\alpha=.93)$ refers to their expectancy for success, judgments of their ability to accomplish the course, and confidence in their skills to perform when studying the course. The learning strategies scales comprise two sub-scales: metacognitive selfregulation and peer learning. Metacognitive self-regulation $(\alpha=.79)$ refers to the use of 
strategies that help students control and regulate their own cognition, i.e. planning, monitoring, and regulation. Peer learning $(\alpha=.96)$ refers to the use of a study group or friends to help them. All of the original items in MSLQ were scrutinised and adapted in order to reflect the learning context specific to this ITE programme.

It is not the intention of this paper to delineate the design process for the MDAQ, but it is important to outline the rationale behind the items in it. Conceptualising professional dialogue as a sociocultural and dialogical practice, we developed the MDAQ in order to highlight the dynamic relationship between thought and communication and the contexts in which professional dialogue was situated. To this end, we considered three dimensions of this professional learning experience. The first dimension relates to the extent to which student teachers' awareness of the linguistic nuances and discourse feature can have an impact on their learning. The second dimension describes the extent to which student teachers are aware of their own thinking processes and monitor their counterparts' thinking as they discuss a particular topic. The third dimension refers to student teachers' awareness of the degree to which social and affective contexts play a role in their learning. As an off-line event instrument (Howard-Rose \& Winne, 1993) for exploring participants' professional dialogue experiences, the MDAQ supported student teachers in creating and regulating a dialogic space for their own professional learning. It was an attempt to synthesise professional dialogue, reflective practices, and professional learning. Sample items within the three dimensions of the MDAQ are listed in Table 1:

Table 1. Sample items from the MDAQ. 
Apart from the MDAQ and the MLSQ we collected a number of demographic characteristics including gender, age and parental education. For a summary of descriptive statistics in our sample of student teachers see Table 2.

Table 2. Descriptive statistics.

\section{Data analysis}

For the quantitative data, we conducted descriptive statistics to provide the numerical explanations for participants' demographics, professional dialogue indicators and general approaches to professional learning. Descriptive statistics included measurements of percentages, means and standard deviations. To answer the first research question on the factors contributing student teachers' general approaches to professional learning, two sample t-tests were conducted. To answer the second research question on the relationship between student teachers' approaches to learning and their professional dialogue experience, correlation analyses were conducted. To answer the final research question on student teachers' perceptions of professional dialogue as a professional learning tool, thematic analysis was used. The data analysis process for the qualitative data was inductive. We first examined whether any regular patters and common themes emerged. Attention was paid to texts regarding professional learning and professional dialogue. These emerging themes were identified and coded (Cohen, Manion and Morrison, 2000). As a way of using open coding principles (Corbin and Strauss, 2008), the data were scrutinised and broken down into meaningful units before categories were given.

\section{Ethical considerations}


The design, data collection and analysis followed the guidelines set out in the BERA Ethical Guidelines for Educational Research (2018), especially regarding informed consent, confidentiality and anonymity. All participants gave informed consent in writing prior to participating in the research and their identities were not revealed.

\section{Findings and Discussion}

Factors contributing to student teachers' general approaches to learning on an ITE programme

The quantitative data provided us with student teachers' insights into the general patterns of their learning approaches on the ITE programme. The factors we examined are 1) judgments of how interesting, useful and important the PGDE programme is; 2) the perceived confidence in their skills to complete the programme successfully; 3 ) the use of learning strategies to regulate their own cognition; 4) the use of peers to help them learn. From the findings, it is possible to see initial patterns emerging, e.g. whether student teachers adopt different learning strategies when they are on campus or in a school environment. The following tables demonstrate group differences in student teachers' general approaches to learning in two-sample t-tests.

Table 3 Results of t-tests and descriptive statistics: general approaches to learning by sex.

Table 4 Results of t-tests and descriptive statistics: general approaches to learning by PGDE course.

Table 5 Results of t-tests and descriptive statistics: general approaches to learning by place of learning. 
Table 6 Results of t-tests and descriptive statistics: general approaches to learning by parental background.

Table 7 Results of t-tests and descriptive statistics: general approaches to learning by age.

Table 3 shows that male students, on average, value the PGDE programme more than female students. This group difference is significant at conventional criteria. Table 4 indicates that Primary Education students are significantly more likely to believe that they will succeed than Secondary Education students. Furthermore, table 5 reveals that student teachers are more likely to be confident in their skills to succeed when they are on school placements. Students, whose parents have no degree, have significantly higher value on the PDGE than students with at least one parent with a degree (table 6). They also use more metacognitive strategies that help students control and regulate their own cognition than their counterparts with higher parental education. Finally, table 7 shows that older student teachers, on average, value the PGDE programme more than younger students.

\section{The relationship between student teachers' approaches to learning and their} professional dialogue experience

Table 8 Correlation matrix between student teachers' approaches to professional learning and their professional dialogue experiences.

For the second research question, we explored the relationship between student teachers' approaches to learning and their professional dialogue experience. Table 8 shows that thought, discourse and social-affect in professional dialogue are significantly 
inter-related, which means that when student teachers are aware of one dimension, they tend to be aware of all three. Furthermore, the table shows that there is medium-strong correlation between discourse and metacognition. However, it is important to note that the professional dialogue experiences that we have examined in this study are highly contextualised. Due to the fact that we adopted an off-line event measurement for professional dialogue (Endedijk et al., 2016; Howard-Rose \& Winne, 1993), participants' responses were based on their reflection of specific episodes; the factors which are correlated may only be the case in these contexts. We must be cautious when generalising the results. The table also shows high level of task value is correlated with high self-efficacy and high metacognition: namely, if student teachers find the PGDE programme useful and important, they are more likely to believe that they can succeed, and they are also more likely to think about their own learning strategies or be conscious about the way they learn during professional dialogue.

\section{Student teachers' perceptions of professional dialogue as a professional learning tool}

As was discussed earlier, reflection is one of the central goals of teacher education (Schön, 1983). Schön's notion 'reflection-on-action' highlights how practice can be improved after the incident has occurred. The type of reflection examined in this study is 'reflection-on-action'. It is retrospective in nature. With regard to the third research question, our findings underline the importance of student teachers reflecting on their professional dialogue experience as a way of discussing alternative views and supporting their own claims with evidence, which contributes to their professional learning and future classroom practice. 


\begin{abstract}
This impacted my practice in that I started to see some of the benefits of a behaviourist and strict discipline approach that were not promoted during university classes in workshops. (Campus 3)
\end{abstract}

This discussion enabled me to clarify and elaborate on ideas about writing that had previously existed more vaguely, and has led to me seeking out research on the subject and endeavouring to consider carefully the role and motivation for writing in my classroom. (Campus 11)

As both student students have pointed out, the professional dialogue experience allowed them to think back about their existing knowledge and beliefs in relation to educational theories and practice. Campus 3 linked their placement experience with university learning as $\mathrm{s} /$ he questions the benefits of behaviourist approaches. Campus 11 was previously unsure about ways to teaching writing in an English class. The professional dialogue s/he had in university settings made them notice the gap in their knowledge. As a follow-up of the discussion, s/he decided to look into the research on this topic. Whether it was through further independent research about certain pedagogical approaches or through the questioning of prior learning, professional dialogue played a vital role in facilitating teacher professional learning and the development of reflective skills. The findings also suggest that teachers' reflection of professional dialogue can be overly simplistic as the following extract illustrates.

$$
\begin{aligned}
& \text { Following the discussion... we both had realised that there is no need to make your } \\
& \text { own resources if the school has better quality and previously tested resources. After } \\
& \text { that discussion I began to search the cupboards in the school and use their } \\
& \text { resources across a range of different curricular areas. (Placement 16) }
\end{aligned}
$$

Student teachers' reflection of professional dialogue can also be merely accounts of their own practices without consideration of the underlying educational issues, theories or implications for their own professional learning. Placement 16, for example, is about 
student teachers' understanding of the value of material development. The justifications of 'what they learned from the professional dialogue' and 'what impact did it have on their practice' were limited to reusing existing school resources. This shows that although some student teachers were able to make connections between their academic reading and their placement experiences, others appeared to have trouble engaging in deeper and more systematic reflection of their professional dialogue.

The findings indicate that the professional dialogue experiences can be 'onesided' and dominated by the university tutor or school mentor. There were little opportunities for the dialogue to be dialogic and co-constructive. Moreover, it appeared that the topics of professional dialogue were mostly pre-determined. The most commonly cited examples were the post-observation conversation between the visiting tutor and the student.

\begin{abstract}
A review of my shared observation when I was asked how my lesson went. I learned that I need to control what I put in my lessons, not just complete the workbook in order that the school tells you to do and it is ok to show pupils the majority of what to do in an experiment. In future I will think more about what is main thing I want pupils to learn in each lesson. (Placement 13)
\end{abstract}

\begin{abstract}
After my observed lesson i.e. crit, I was sure that I had failed however my mentor said the lesson had been fine and for last period on a Monday, I had managed to keep the class to an acceptable level of control. (Placement 22)
\end{abstract}

The reflections provided by Placement 13 and Placement 22 were examples of 'onesided' professional dialogue where student teachers were told how the observed lessons went and what they should do in the future. Student teachers used phrases such as 'I learned that I need to ...', 'it is ok to ...', and 'my mentor said ...' This type of professional dialogue limits the depth of teacher professional learning as it tends to be 
dominated by one speaker (usually the university tutor or the school mentor).

Consequently, student teachers' own reflection and perspectives can be ignored.

\section{Discussion}

This study was an attempt to explore the nature of professional dialogue experiences of student teachers from a sociocultural and dialogical perspective. In order to further our understanding of student teachers' learning in professional dialogue, we have adopted a sociocultural and dialogical perspective on thinking and communication. In combination with student teachers' reflection, we hoped to develop a better understanding of the process as a co-construction and negotiation of meaning. Not only did the paper contribute to generating detailed empirical evidence towards teacher professional learning at the pre-service stage, it also contributed to the theoretical debates concerning the importance of teachers learning how to learn - from themselves and others, as well as, in and from practice.

In line with the literature, the findings suggest that professional dialogue not only improves teacher knowledge and practice (Simoncini et al., 2014), but also enhances the quality of reflective practice (Rocco, 2010). Both Campus 3 and Campus 11 regard professional dialogue as a professional learning tool to develop their pedagogical knowledge and to question their prior learning at university settings. Reflective professional dialogue supports teacher self-regulation in which they think back and forward along the different phases of their own learning, and articulate tacit knowledge so as to deepen their understanding of learning and teaching in practice (Kramarski \& Kohen, 2016; Paris \& Winograd, 2003). Therefore, professional dialogue provides student teachers with the opportunities to convert tacit knowledge into shared knowledge (Fullan, 2001). 
The reciprocal interrelationship between professional dialogue and reflective practices has been the highlight of this paper. Hatton and Smith (1995) note that rather than assuming that student teachers have the ability to reflect spontaneously, they should be introduced to reflection during ITE. Hobbs (2007) also warns that not everyone has a predisposition towards reflection. Indeed, as Lofthouse and Hall (2014) shows, teachers' reflective skills tend to be mostly technical in nature. There is often a lack of scrutinising different approaches to teaching in an attentive and critical way (Feiman-Nemser, 2001). Therefore, we argue that not only is there a need for ITE providers to enhance and support opportunities for professional dialogue, but that it is arguably more important to create a space in which connections between theory and practice can be made. As student teachers in our study have reported, combining professional dialogue with reflection helped them develop the necessary skills and dispositions of reflective practitioners.

One of the aims of the present study is to encourage student teachers to attend to a range of metacognitive, discourse and social-affective strategies so that they could become more self-aware of their role as reflective agents for change. The extracts by Placement 13 and Placement 22 suggest that neither the student teachers nor their counterparts seemed to be aware of the nuances of the range of discursive strategies to create a genuine dialogic space. Rather than co-constructing and negotiating a shared understanding of the lesson, student teachers were told how it went and what they should go in the future. This way of engaging in professional dialogue, or rather monologue, can be the result of a lack of the awareness of strategies for metacognitive monitoring and control across all three dimensions: discourse, thought and social-affect. One of the outcomes, therefore, was to raise student teachers' awareness of the dialogic nature of professional dialogue and the three dimensions which contribute to the 
creation of such dialogical space. We argue that (the reflection of) professional dialogue in diverse learning contexts should be used as a tool for various stages of a teacher's career.

Our findings suggest that professional dialogue (discourse), metacognition (thinking), and approaches to professional learning are three interlinked components of teacher professional learning. In their study of teachers as metacognitive role models, Wall and Hall (2016) highlighted the interlinked nature of teachers' metacognitive awareness, classroom dialogue and strategic and reflective thinking. In line with this, our findings confirm that reflection/reflective practices do indeed play a crucial role in the development of all three components, suggesting that they should not be seen as distinct. Furthermore in accord with Mercer and Howe's (2012) work, we argue that future interventions on improving the quality of professional dialogue should aim to raise student teachers' metacognitive awareness. The recognition of the value of how talk can be used effectively for learning as well as its potential as a cultural and psychological tool can help to consolidate student teacher professional learning.

Finally, our study highlights the different conditions and contexts that professional dialogue creates, and suggests that student teachers value the opportunity to discuss educational issues and solutions to learning and teaching problems within a university context. Portilho and Medina (2016) indicated that metacognition as methodology for teacher education provided space for teachers to reflect on their own practice by talking, listening, discussing and learning with their peers. The findings of the present study echo this view. Moreover, we argue that while interaction with peers, university tutors and more experienced teachers gives student teachers the opportunities to examine thinking and practice more carefully, it appears that particular value should 
be placed on opportunities to connect practice to previously learned theory and knowledge from university based ITE.

\section{Conclusion}

In attempting to explore the nature of professional dialogue experiences of student teachers, our research has shown the inherent complexity involved in this process, which relies on three interlinked components of professional learning to operate in synergy. Our research has also highlighted the importance of both school and university-based professional learning for this synergy. However, given the recent moves by the government in Scotland to create a more 'streamlined' approach to professional learning alongside fast track, school-based forms of ITE, it is difficult to see where this can take place. Although our findings have shown that professional dialogue can be a useful professional learning tool, it is clear that more must be done in ITE to raise awareness amongst students. If the role of university-based learning is reduced and ITE programmes are further squeezed of their content, it is unlikely that professional dialogue will be given the attention that it requires. This means that much of it will be left for student teachers to 'work out' alongside teachers 'on the job', who may also have a limited understanding of the nuances and factors involved. This in turn may have significant implications for the extent to which student teachers can use professional dialogue to improve the learning and teaching practices in the classroom and to broaden their own professional learning opportunities.

\section{Acknowledgements}

This paper was presented at the European Educational Research Association annual conference in Copenhagen, August 2017. The authors were grateful to the students who participated in this study, and to Kate Wall and the anonymous reviewers who offered their feedback on various drafts of this manuscript. 


\section{References}

BERA. (2018). Ethical Guidelines for Educational Research Fourth Edition (4th ed.). London: British Educational Research Association (BERA). https://doi.org/978-0946671-32-8

Bereiter, C., \& Scardamalia, M. (1993). Surpassing ourselves: An inquiry into the nature and implications of expertise. Chicago: Open Court.

Boekaerts, M. (2006). Self-regulation and effort investment. In E. Sigel \& K. A. Renninger (Eds.), Handbook of child psychology (pp. 345-377). Hoboken: Wiley.

Cochran-Smith, M. (2003). Learning and unlearning: The education of teacher educators. Teaching and Teacher Education, 19(1), 5-28. https://doi.org/http://dx.doi.org/10.1016/S0742-051X(02)00091-4

Cochran-Smith, M., \& Lytle, S. L. (1999). Relationships of knowledge and practice: Teacher learning in communities. Review of Research in Education, 249-305.

Cohen, L., Manion, L. and Morrison, K. 2000. Research methods in education, London: Routledge Falmer.

Corbin, J. and Strauss, A. 2008. Basics of qualitative research: Techniques and procedures for developing grounded theory, London: Sage.

Darling-Hammond, L. (2017). Teacher education around the world: What can we learn from international practice. European Journal of Teacher Education, 40(3), 291301.

Dolan, A. M. (2012). Reforming teacher education in the context of lifelong learning: the case of the BEd degree programme in Ireland. European Journal of Teacher Education, 35(4), 463-479. https://doi.org/10.1080/02619768.2012.696190

Donaldson, G. (2011). Teaching Scotland's Future: Report of a review of teacher education in Scotland. The Scottish Government. Edinburgh: The Scottish Government. Retrieved from http://www.gov.scot/Resource/Doc/337626/0110852.pdf 
Duncan, T. G., \& McKeachie, W. J. (2005). The making of the motivated strategies for learning questionnaire. Educational Psychologist, 40(2), 117-128. https://doi.org/10.1207/s15326985ep4002_6

Endedijk, M. D., Brekelmans, M., Sleegers, P., \& Vermunt, J. D. (2016). Measuring students' self-regulated learning in professional education: bridging the gap between event and aptitude measurements. Quality \& Quantity, 50(5), 2141-2164. https://doi.org/10.1007/s11135-015-0255-4

Feiman-Nemser, S. (2001). From preparation to practice: Designing a continuum to strengthen and sustain teaching. Teachers College Record, 103, 1013-1055.

Fullan, M. (2001). The new meaning of educational change (3rd ed.). New York and London: Teachers College Press and RoutledgeFalmer.

Furlong, J., Barton, L., Miles, S., Whiting, C., \& Whitty, G. (2000). Teacher education in transition. Buckingham: Open University Press.

Grant, S., Comber, B., Danby, S., Theobald, M. \& Thorpe, K. (2018). The quality agenda: governance and regulation of preschool teachers' work. Cambridge Journal of Education, 48(4), 515-532. https://doi.org/10.1080/0305764X.2017.1364699

Hatton, N., \& Smith, D. (1995). Reflection in teacher education: towards definition and implementation. Teaching and Teacher Education, 11(1), 33-49.

Hobbs, V. (2007). Faking it or hating it: Can reflective practice be forced? Reflective Practice, 8, 405-417.

Hobson, A. J., \& Malderez, A. (2013). Judgementoring and other threats to realizing the potential of school-based mentoring in teacher education. International Journal of Mentoring and Coaching in Education, 2(2), 89-108.

Howard-Rose, D., \& Winne, P. (1993). Measuring component and sets of cognitive processes in self-regulated learning. Journal of Educational Psychology, 85(4), 591-604. 
Kemmis, S., \& Grootenboer, P. (2008). Situating praxis in practice: Practice architectures and the cultural, social and material conditions for practice. In S. Kemmis \& T. J. Smith (Eds.), Enabling praxis: Challenges for education (pp. 3764). Rotterdam: Sense Publishers.

Kemmis, S., \& Heikkinen, H. L. T. (2012). Practice architectures and teacher induction. In H. L. T. Heikkinen, H. Jokinen, \& P. Tynjälä (Eds.), Peer-group mentoring (PGM): Peer group mentoring for teachers' professional development (pp. 144179). London: Routledge.

Kennedy, A. (2013). Teacher professional learning. In T. G. K. Bryce, W. M. Humes, D. Gillies, \& A. Kennedy (Eds.), Scottish Education (4th ed., pp. 927-937). Edinburgh: Edinburgh University Press.

Kennedy, A. (2015). What do professional learning policies say about purposes of teacher education? Asia-Pacific Journal of Teacher Education, 43(3), 183-194.

Kennedy, A., \& Author. (2019). Teacher professional learning. In T. G. K. Bryce, W. M. Humes, D. Gillies, \& A. Kennedy (Eds.), Scottish Education (5th ed., pp. 847857). Edinburgh: Edinburgh University Press.

Kramarski, B., \& Kohen, Z. (2016). Promoting preservice teachers' dual self-regulation roles as learners and as teachers: effects of generic vs. specific prompts. Metacognition and Learning. https://doi.org/10.1007/s11409-016-9164-8

Lieberman, A., \& Mace, D. H. P. (2008). Teacher learning: The key to educational reform. Journal of Teacher Education, 59(3), 226-234. https://doi.org/10.1177/0022487108317020

Littleton, K., \& Mercer, N. (2013). Interthinking: Putting talk to work. Abingdon: Routledge.

Lofthouse, R., \& Hall, E. (2014). Developing practices in teachers' professional dialogue in England: using Coaching Dimensions as an epistemic tool. Professional Development in Education, 40(5), 758-778. https://doi.org/10.1080/19415257.2014.886283 
Mayer, D., Allard, A., Moss, J. \& Dixon, M. (2016). Initial Teacher Education and Assessment of Graduates in Australia. In J. Chi-Kin \& L. C. Day (Eds.) Quality and change in teacher education: Western and Chinese perspectives (pp. 149-162). Hong Kong: Springer.

Mazurkiewicz, G. (2003). How professional dialogue prevents burnout. In M. Scherer (Ed.), Keeping good teachers (pp. 169-175). Alexandria, VA: Association for Supervision and Curriculum Development.

Menter, I., Hulme, M., Elliot, D., \& Lewin, J. (2010). Literature Review on Teacher Education in the 21st Century. Edinburgh: Scottish Government Retrieved from http://www.gov.scot/Publications/2010/09/24144019/0 (Updated 6.12.17).

Mercer, N., \& Howe, C. (2012). Explaining the dialogic processes of teaching and learning: The value and potential of sociocultural theory. Learning, Culture and Social Interaction, 1(1), 12-21. https://doi.org/10.1016/j.lcsi.2012.03.001

Mercer, N., \& Littleton, K. (2007). Dialogue and the development of children's thinking: A sociocultural approach. London: Routledge.

Michalsky, T., \& Kramarski. (2015). Prompting reflections for integrating selfregulation into teacher technology education. Teachers College Record, 117(5), 138.

Munthe, E., Malmo, K. A. S., \& Rogne, M. (2011). Teacher education reform and challenges in Norway. Journal of Education for Teaching, 37(4), 441-450. https://doi.org/10.1080/02607476.2011.611012

Murray, J., \& Mutton, T. (2016). Teacher education in England: change in abundance, continuities in question. In G. Beauchamp, L. Clarke, M. Humes, M. Jephcote, A. Kennedy, G. Magennis, ... G. Peiser (Eds.), Teacher education in times of change (pp. 57-74). Bristol: Policy Press.

Nelson, T., Deuel, A., Slavit, D., \& Kennedy, A. (2010). Leading deep conversations in collaborative inquiry groups. The Clearing House, 83(5), 175-179. https://doi.org/10.1080/00098650903505498 
Paris, S. G., \& Winograd, P. (2003). The Role of self-Regulated learning in contextual teaching: Principles for teacher preparation [Commissioned Paper]. Washington, D.C.

Philipp, R. A. (2007). Mathematics teachers' beliefs and affect. In F. K. Lester (Ed.), Second handbook of research on mathematics teaching and learning (pp. 257315). Charlotte: NCTM/Information Ages Publishing.

Pintrich, P. (2000). The role of goal orientation in self-regulated learning. In M. Boekaerts, P. Pintrich, \& M. Zeidner (Eds.), Handbook of Self-regulation: Theory, Research and Applications (pp. 452-502). San Diego, CA: Academic.

Pintrich, P. (2004). A conceptual framework for assessing motivation and self-regulated learning in college students. Educational Psychology Review, 16, 385-407.

Pintrich, P., Smith, D. A. F., García, T., \& McKeachie, W. J. (1993). Reliability and predictive validity of the Motivated Strategies for Learning Questionnaire (MSLQ). Educational and Psychological Measurement, 55(3), 801-813. https://doi.org/10.1177/0013164493053003024

Pollard, A. (2008). Reflective teaching: Evidence-informed professional practice (3rd ed.). London: Continuum.

Pollard, A., \& Tann, S. (1987). Reflective teaching in the primary school. London: Cassel.

Portilho, E. M. L., \& Medina, G. B. K. (2016). Metacognition as Methodology for Continuing Education of Teachers. Creative Education, 07(01), 1-12. https://doi.org/10.4236/ce.2016.71001

Rocco, S. (2010). Making reflection public: Using interactive online discussion board to enhance student learning. Reflective Practice, 11(3), 307-317. https://doi.org/http://dx.doi.org/10.1080/14623943.2010.487374

Routman, R. (2002). Teacher talk. Educational Leadership, 59(6), 32-35.

Sachs, J. (2016). Teacher professionalism: why are we still talking about it? Teachers 
and Teaching: Theory and Practice, 22, 413-425.

Schön, D. (1983). The reflective practitioner: How professionals think in action. London: Basic Books.

Schön, D. (1987). Educating the reflective practitioner. San Francisco: Jossey-Bass.

Scottish Government. (2017). Education governance: next steps: Empowering our teachers, parents and communities to deliver excellence and equity for our children. Edinburgh: Scottish Government.

Simoncini, K. M., Lasen, M., \& Rocco, S. (2014). Professional Dialogue, Reflective Practice and Teacher Research: Engaging Early Childhood Pre-Service Teachers in Collegial Dialogue about Curriculum Innovation. Australian Journal of Teacher Education, 39(1), 19.

Vygotsky, L. S. (1978). Mind in society: The development of higher psychological processes. Cambridge, MA: Harvard University Press.

Walkington, J. (2005). Becoming a teacher: Encouraging development of teacher identity through reflective practice. Asia-Pacific Journal of Teacher Education, 33(1), 53-64.

Wall, K., \& Hall, E. (2016). Teachers as metacognitive role models. European Journal of Teacher Education, 39(4), 403-418. https://doi.org/10.1080/02619768.2016.1212834

Wall, K., \& Hall, E. (2017b). The teacher in teacher-practitioner research: Three principles of inquiry. In P. Boyd \& A. Szplit (Eds.), International perspectives: tachers and teacher educators learning through enquiry. Kielce, Kraków: The Association for Teachers Education in Europe.

Warwick, P., Vrikki, M., Vermunt, J. D., Mercer, N., \& van Halem, N. (2016). Connecting observations of student and teacher learning: An examination of dialogic processes in Lesson Study discussions in mathematics. ZDM Mathematics Education, 48(4), 555-569. https://doi.org/10.1007/s11858-015-0750-z

Wegerif, R. (2007). Dialogic education and technology: Expanding the space of 
learning. Devon, UK: Springer.

Wells, G. (1999). Dialogic Inquiry: Toward a Sociocultural Practice and Theory of Education. Cambridge: Cambridge University Press.

Winne, P. H., \& Hadwin, A. F. (1998). Studying as self-regulated learning. In D. J. Hacker, J. Dunlosky, \& A. C. Graesser (Eds.), Metacognition in Educational Theory and Practice (pp. 277-304). New York: Routledge.

Zimmerman, B. J. (2000). Attaining self-regulation: A social cognitive perspective. In M. Boekaerts, P. R. Pintrich, \& M. Zeidner (Eds.), Handbook of Self-regulation (pp. 13-39). San Diago, CA: Academic Press. 


\section{Appendix: Tables}

Table 1 Sample items from the MDAQ.

\begin{tabular}{|c|c|}
\hline Dimension & Sample Items \\
\hline The discourse dimension & $\begin{array}{l}\text { I tried to clarify what the other person } \\
\text { had said when something was not } \\
\text { clear. } \\
\text { - I asked questions to seek relevant or } \\
\text { further information. } \\
\text { - I expressed agreement and shared } \\
\text { ideas as the conversation progressed. }\end{array}$ \\
\hline The thought dimension & $\begin{array}{l}\text { I made connections to my own prior } \\
\text { learning and experience in the } \\
\text { discussion. } \\
\text { - I expected to learn something from our } \\
\text { discussion. } \\
\text { - The more we discussed the issue, the } \\
\text { more difficult/complicated it seem to } \\
\text { have become. }\end{array}$ \\
\hline The social-affective dimension & $\begin{array}{l}\text { - I positioned myself as a student rather } \\
\text { than a teacher in the discussion. } \\
\text { - I felt comfortable as I shared my ideas } \\
\text { as long as they were relevant. } \\
\text { - I was interested in listening to the } \\
\text { other person's views and opinions. }\end{array}$ \\
\hline
\end{tabular}

Table 2 Descriptive statistics.

\begin{tabular}{llllll}
\hline & Percentage & Mean & SD & Min & Max \\
\hline Gender & & & & \\
Male & 29.63 & & & \\
Female & 70.37 & & &
\end{tabular}


Parental education

No degree

At least one parent with

degree

PGDE course

Primary

Secondary

Place of learning

Campus

Placement

52.54

Age

21

48

Professional dialogue

experiences indicators

Thought dimension

55.35

7.58

42

76

Discourse dimension

57.44

9.34

35

76

Social-affective dimension

60.86

5.91

48

73

General approaches to

learning

Task value

24.35

4.39

11

30

Self-efficacy

37.44

6.37

20

48

Metacognition

49.48

10.24

19

67

Peer learning

11.28

4.10

18

Source: Survey among PGDE students at University of Strathclyde; Note: $\mathrm{M}=\mathrm{Mean}, \mathrm{SD}=$ Standard

Deviation, $\min =$ Minimum, $\max =$ Maximum

Table 3 Results of t-tests and descriptive statistics: general approaches to learning by sex.

\begin{tabular}{|c|c|c|c|c|c|c|c|c|c|}
\hline \multirow[t]{3}{*}{ Outcome } & \multicolumn{6}{|l|}{ Group } & \multirow{2}{*}{\multicolumn{3}{|c|}{$\begin{array}{l}95 \% \text { CI for } \\
\text { Mean }\end{array}$}} \\
\hline & \multicolumn{3}{|c|}{ Female } & \multicolumn{3}{|l|}{ Male } & & & \\
\hline & $\mathrm{M}$ & SD & $\mathrm{n}$ & $\mathrm{M}$ & SD & $\mathrm{n}$ & Difference & $\mathrm{t}$ & df \\
\hline Task value & 23.81 & 4.52 & 36 & 26.63 & 2.96 & 16 & $-5.30,-0.33$ & $-2.28 *$ & 50 \\
\hline Self-efficacy & 37.74 & 6.01 & 38 & 37.38 & 7.83 & 16 & $-3.58,4.30$ & 0.18 & 52 \\
\hline
\end{tabular}


Metacogniti

on

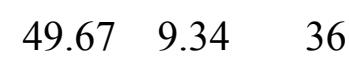

47.31

12.64

16

$-3.94,8.65$

0.75

50

Peer

learning

$$
11.68 \quad 4.11 \quad 37
$$

$10.94 \quad 3.97$

$16-1.71,3.18$

0.61

51

Source: Survey among PGDE students at University of Strathclyde; Note: M=Mean, SD=Standard

Deviation, $\mathrm{CI}=$ Confidence interval, $\mathrm{df}=$ Degrees of freedom; * $\mathrm{p}<.05$.

Table 4 Results of t-tests and descriptive statistics: general approaches to learning by

\begin{tabular}{|c|c|c|c|c|c|c|c|c|c|}
\hline \multirow[t]{3}{*}{ Outcome } & \multirow{2}{*}{\multicolumn{3}{|c|}{$\begin{array}{l}\text { Group } \\
\text { PGDE Primary }\end{array}$}} & & & & \multirow{3}{*}{$\begin{array}{l}\text { 95\% CI for } \\
\text { Mean } \\
\text { Difference }\end{array}$} & \multirow[b]{3}{*}{$\mathrm{t}$} & \multirow[b]{3}{*}{$\mathrm{df}$} \\
\hline & & & & \multicolumn{3}{|c|}{ PGDE Secondary } & & & \\
\hline & $\mathrm{M}$ & SD & $\mathrm{n}$ & $\mathrm{M}$ & SD & $\mathrm{n}$ & & & \\
\hline Task value & 26.29 & 2.33 & 14 & 23.72 & 4.73 & 43 & $-0.07,5.21$ & 1.95 & 55 \\
\hline Self-efficacy & 40.56 & 6.65 & 16 & 36.28 & 5.93 & 43 & $0.69,7.88$ & $2.39 *$ & 57 \\
\hline $\begin{array}{l}\text { Metacogniti } \\
\text { on }\end{array}$ & 50.13 & 13.28 & 15 & 49.24 & 9.08 & 41 & $-5.36,7.14$ & 0.29 & 54 \\
\hline $\begin{array}{l}\text { Peer } \\
\text { learning }\end{array}$ & 12.13 & 4.56 & 16 & 10.95 & 3.92 & 42 & $-1.24,3.59$ & 0.97 & 56 \\
\hline
\end{tabular}

PGDE course.

Source: Survey among PGDE students at University of Strathclyde; Note: $\mathrm{M}=$ Mean, $\mathrm{SD}=$ Standard

Deviation, $\mathrm{CI}=$ Confidence interval, $\mathrm{df}=$ Degrees of freedom; * $\mathrm{p}<.05$.

Table 5 Results of t-tests and descriptive statistics: general approaches to learning by

\begin{tabular}{|c|c|c|c|c|c|c|c|c|c|}
\hline \multirow[t]{3}{*}{ Outcome } & \multicolumn{6}{|l|}{ Group } & \multirow{2}{*}{\multicolumn{3}{|c|}{$\begin{array}{l}95 \% \text { CI for } \\
\text { Mean }\end{array}$}} \\
\hline & \multicolumn{3}{|c|}{ Campus } & \multicolumn{3}{|c|}{ Placement } & & & \\
\hline & $\mathrm{M}$ & SD & $\mathrm{n}$ & $\mathrm{M}$ & $\mathrm{SD}$ & $\mathrm{n}$ & Difference & $\mathrm{t}$ & $\mathrm{df}$ \\
\hline Task value & 23.33 & 4.69 & 27 & 25.27 & 3.96 & 30 & $-4.23,0.36$ & -1.69 & 55 \\
\hline Self-efficacy & 35.54 & 6.81 & 28 & 39.16 & 5.50 & 31 & $-6.84,-0.41$ & $-2.26^{*}$ & 57 \\
\hline $\begin{array}{l}\text { Metacogniti } \\
\text { on }\end{array}$ & 49.81 & 9.26 & 27 & 49.17 & 11.24 & 29 & $-4.90,6.18$ & 0.23 & 54 \\
\hline $\begin{array}{l}\text { Peer } \\
\text { learning }\end{array}$ & 10.93 & 4.26 & 27 & 11.58 & 4.00 & 31 & $-2.83,2.52$ & -0.60 & 56 \\
\hline
\end{tabular}
place of learning.

Source: Survey among PGDE students at University of Strathclyde; Note: $\mathrm{M}=\mathrm{Mean}, \mathrm{SD}=$ Standard

Deviation, $\mathrm{CI}=$ Confidence interval, $\mathrm{df}=$ Degrees of freedom; ${ }^{*} \mathrm{p}<.05$. 
Table 6 Results of t-tests and descriptive statistics: general approaches to learning by parental background.

\begin{tabular}{|c|c|c|c|c|c|c|c|c|c|}
\hline \multirow[t]{3}{*}{ Outcome } & \multicolumn{6}{|l|}{ Group } & \multirow{3}{*}{$\begin{array}{l}\text { 95\% CI for } \\
\text { Mean } \\
\text { Difference }\end{array}$} & \multirow[b]{3}{*}{$\mathrm{t}$} & \multirow[b]{3}{*}{ df } \\
\hline & \multicolumn{3}{|c|}{$\begin{array}{l}\text { Parents with no } \\
\text { degree }\end{array}$} & \multicolumn{3}{|c|}{$\begin{array}{l}\text { At least one parent } \\
\text { with degree }\end{array}$} & & & \\
\hline & $\mathrm{M}$ & SD & $\mathrm{n}$ & $\mathrm{M}$ & SD & $\mathrm{n}$ & & & \\
\hline Task value & 25.87 & 3.13 & 31 & 22.53 & 5.01 & 26 & $1.15,5.51$ & $3.06^{*}$ & 55 \\
\hline Self-efficacy & 38.53 & 5.75 & 32 & 36.15 & 6.92 & 27 & $-0.92,5.68$ & 1.45 & 57 \\
\hline $\begin{array}{l}\text { Metacogniti } \\
\text { on }\end{array}$ & 52.07 & 7.4 & 30 & 46.5 & 12.24 & 26 & $0.22,10.90$ & $2.09 *$ & 54 \\
\hline $\begin{array}{l}\text { Peer } \\
\text { learning }\end{array}$ & 11.03 & 3.93 & 31 & 11.56 & 4.34 & 27 & $-2.70,1.65$ & -0.48 & 56 \\
\hline
\end{tabular}

Source: Survey among PGDE students at University of Strathclyde; Note: M=Mean, SD=Standard

Deviation, $\mathrm{CI}=$ Confidence interval, $\mathrm{df}=$ Degrees of freedom; $* \mathrm{p}<.05$.

Table 7 Results of t-tests and descriptive statistics: general approaches to learning by age.

\begin{tabular}{|c|c|c|c|c|c|c|c|c|c|}
\hline \multirow[t]{3}{*}{ Outcome } & \multicolumn{4}{|c|}{ Group } & $V$ & & \multirow{2}{*}{\multicolumn{3}{|c|}{$\begin{array}{l}95 \% \text { CI for } \\
\text { Mean }\end{array}$}} \\
\hline & \multicolumn{3}{|c|}{ Age 20-29 } & \multicolumn{3}{|c|}{ Above age 30} & & & \\
\hline & $\mathrm{M}$ & SD & $\mathrm{n}$ & $\mathrm{M}$ & SD & $\mathrm{n}$ & Difference & $\mathrm{t}$ & df \\
\hline Task value & 23.42 & 4.81 & 38 & 26.39 & 2.57 & 18 & $-5.40,-0.54$ & $-2.45^{*}$ & 54 \\
\hline Self-efficacy & 37.31 & 6.80 & 39 & 38.00 & 5.57 & 19 & $-4.30,2.91$ & -0.38 & 56 \\
\hline $\begin{array}{l}\text { Metacogniti } \\
\text { on }\end{array}$ & 47.79 & 11.30 & 39 & 53.35 & 12.24 & 17 & $-11.39,0.27$ & -1.91 & 54 \\
\hline $\begin{array}{l}\text { Peer } \\
\text { learning }\end{array}$ & 11.32 & 4.06 & 38 & 11.47 & 4.21 & 19 & $-2.47,2.16$ & -0.14 & 55 \\
\hline
\end{tabular}

Source: Survey among PGDE students at University of Strathclyde; Note: M=Mean, SD=Standard Deviation, $\mathrm{CI}=$ Confidence interval, $\mathrm{df}=$ Degrees of freedom; * $\mathrm{p}<.05$.

Table 8 Correlation matrix between student teachers' general approaches to learning and their professional dialogue experiences.

\section{Thought Discourse Social-aff. Task value Self-eff. Metacog.}




\begin{tabular}{lllllll}
\hline Thought & - & & & & \\
\hline Discourse & $0.74^{*}$ & - & & & & \\
\hline Social-aff. & $0.66^{*}$ & $0.71^{*}$ & - & & & \\
\hline Task value & 0.17 & 0.18 & 0.12 & - & & \\
\hline Self-eff. & 0.19 & $0.36^{*}$ & $0.37^{*}$ & $0.48^{*}$ & - & - \\
\hline Metacog. & $0.41^{*}$ & $0.48^{*}$ & $0.35^{*}$ & $0.32^{*}$ & 0.26 & - \\
\hline Peer learn. & $0.26^{*}$ & 0.26 & $0.32^{*}$ & 0.10 & $0.35^{*}$ & $0.35^{*}$ \\
\hline
\end{tabular}

Source: Survey among PGDE students at University of Strathclyde; * $\mathrm{p}<.05$. 